\title{
LEAD ACTIVATES CALMODULIN SENSITIVE PROCESSES
}

\author{
Gary W. Goldstein and Diane Ar \\ Departments of Pediatrics and Neurology \\ University of Michigan Medical School \\ Ann Arbor, Michigan 48109
}

(Received in final form June 21, 1983)

Summary

\begin{abstract}
The effect of lead on two calcium sensitive processes was determined. Micromolar concentrations of lead successfully replaced calcium in the activation of calmodulin-sensitive phosphodiesterase and in the promotion of potassium loss from erythrocytes. Both actions of lead were blocked by trifluoperazine--an inhibitor of calmodulin function. We propose that some of the toxic effects of lead may be explained by its interaction with calmodulin.
\end{abstract}

Children poisoned with lead may develop brain injury, muscle weakness, anemia, and renal tubular dysfunction (1). It is well established that calcium influences the absorption and distribution of lead (2), but this observation does not explain the cellular manifestations of lead toxicity. To determine whether lead might alter cell function by substituting for calcium in regulatory processes, we measured the effect of lead upon the activity of two calcium-sensitive reactions. We found that lead could replace calcium in the calmodulin-dependent activation of cyclic nucleotide phosphodiesterase (PDE) and in the promotion of potassium efflux from erythrocytes. Both effects were blocked by trifluoperazine (TFP), an inhibitor of calmodulin action.

\section{Materials and Methods}

The activator deficient PDE and calmodulin used in these experiments were purchased from Sigma Chemical, St. Louis, MO. PDE activity was determined by measuring conversion of cAMP to adenosine (3). The reaction mixture contained $700 \mathrm{H}$ units of bovine heart, activator-deficient PDE with or without $200 \mathrm{ng}$ of phosphodiesteraşe $3^{\prime}: 5^{\prime}$-cyclic nucleotide activator (calmodulin), 20 HM cAMP, and $0.1 \mu \mathrm{Ci}$ of ${ }^{3} \mathrm{H}$-cAMP in a total volume of $100 \mu \mathbf{l}$ calcium-free buffer $(100 \mathrm{mM}$ Tris, $\mathrm{pH} 8.0,1 \mathrm{mM} \mathrm{MgSO}, 600 \mu \mathrm{M}$ dithiothreitol, and $10 \mu \mathrm{M}$ EGTA). The EGTA was added to chelate endogenous calcium. The concentration of lead chloride in the incubation varied from 0 to $100 \mu \mathrm{M}$. To inhibit calmodulin binding to PDE, $20 \mu \mathrm{M}$ TFP was added when the lead concentration was $50 \mu \mathrm{M}$.

The effect of calcium, lead and calmodulin on potassium permeability was studied with red blood cells. Human red blood cells were prepared from fresh heparized blood, washed three times in 20 volumes of ice cold 15 mM HEPES buffered saline, $\mathrm{pH} 7.4$, containing $2 \mathrm{mM} \mathrm{CaCl}$. A cell pellet was prepared by centrifuging red blood cells at $600 \times \mathrm{g}$ for $16 \mathrm{~min}$ and then resuspended in 
3 volumes of ice cold buffer. Incubations were initiated by adding $200 \mu I$ of the red blood cell suspension to $4.8 \mathrm{ml}$ of buffer prewarmed to $37^{\circ} \mathrm{C}$. Calcium entry into the cells was produced with the specific calcium ionophore, A23187. The ionophore was dissolved in DMSO and added to the incubation at time zero in a volume of $5 \mu \mathrm{l}$. The final concentration of A23187 was $0.2 \mu \mathrm{g} / \mathrm{ml}$. DMSO alone had no effect on potassium release. To chelate calcium, the cells were preincubated $10 \mathrm{~min}$ at $37^{\circ} \mathrm{C}$ in $5 \mathrm{mM}$ EGTA. When present, lead chloride was added to the incubation at time zero at a final concentration of $10 \mu \mathrm{M}$. To inhibit calmodulin action the cells were preincubated 5 min with $20 \mu \mathrm{M}$ TFP at $37^{\circ} \mathrm{C}$. The reaction was stopped with $5 \mathrm{ml}$ of ice cold buffer and centrifugation for $10 \mathrm{~min}$ at $600 \mathrm{xg}$. The concentration of potassium in the supernatant was measured using a flame photometer.

\section{$\underline{\text { Results and Discussion }}$}

The role of calmodulin, an intracellular calcium receptor protein, in the regulation of several enzymes and transport systems, has only recently been discovered and the 1 ist of calcium-sensitive reactions modulated by the calmodulin-calcium complex is rapidly expanding $(4,5)$. When the concentration of calcium in the cytosol rises, calcium ions bind to high affinity sites on calmodulin causing the configuration of the protein to change (6). The complex is then able to alter the activity of certain enzymes and transport systems. TFP inhibits this cascade by binding to the calmodulin-calcium complex and preventing its interaction with calcium-sensitive enzymes (7). Since lead is known to have a kinetic behavior similar to calcium in intact cells (8) and to compete with calcium for absorption from the intestine (9), incorporation into bone $(10)$, and accumulation by mitochondria $(11,12)$, we questioned whether lead could replace calcium in the activation of calmodulin.

Figure 1 shows the stimulation of PDE by calmodulin and lead. The incubation buffer has no added calcium and contains $10 \mu \mathrm{M}$ EGTA to remove endogenous calcium. PDE activity increased when the concentration of lead exceeded that of EGTA, a finding explained by the capacity of EGTA to bind lead on an equimolar basis. The stimulation of $\mathrm{PDE}$ by calmodulin and lead was inhibited more than $50 \%$ by $20 \mu \mathrm{M}$ TFP. This is consistent with observations that TFP blocks calmodulin-calcium activation of PDE with an $\mathrm{I}_{5}$ of $10 \mu \mathrm{M}(7)$. Lead had no effect on the activity of PDE in the absence of calmodulin. When PDE was maximally activated by calmodulin and either lead or calcium, addition of the other divalent cation did not change the activity of the enzyme (experiments not shown). From these results we cannot determine the mechanism by which lead activates PDE in the presence of calmodulin, but since divalent cations in addition to calcium (i.e., $\mathrm{Sr}^{++}, \mathrm{Ni}^{++}, \mathrm{Co}^{++}, \mathrm{Zn}^{++}, \mathrm{Mn}^{++}$but not $\mathrm{Ba}^{++}$or $\mathrm{Mg}^{++}$) support the binding of TFP to calmodulin (13), we suspect that lead is acting directly at the high affinity calcium binding sites on calmodulin. 


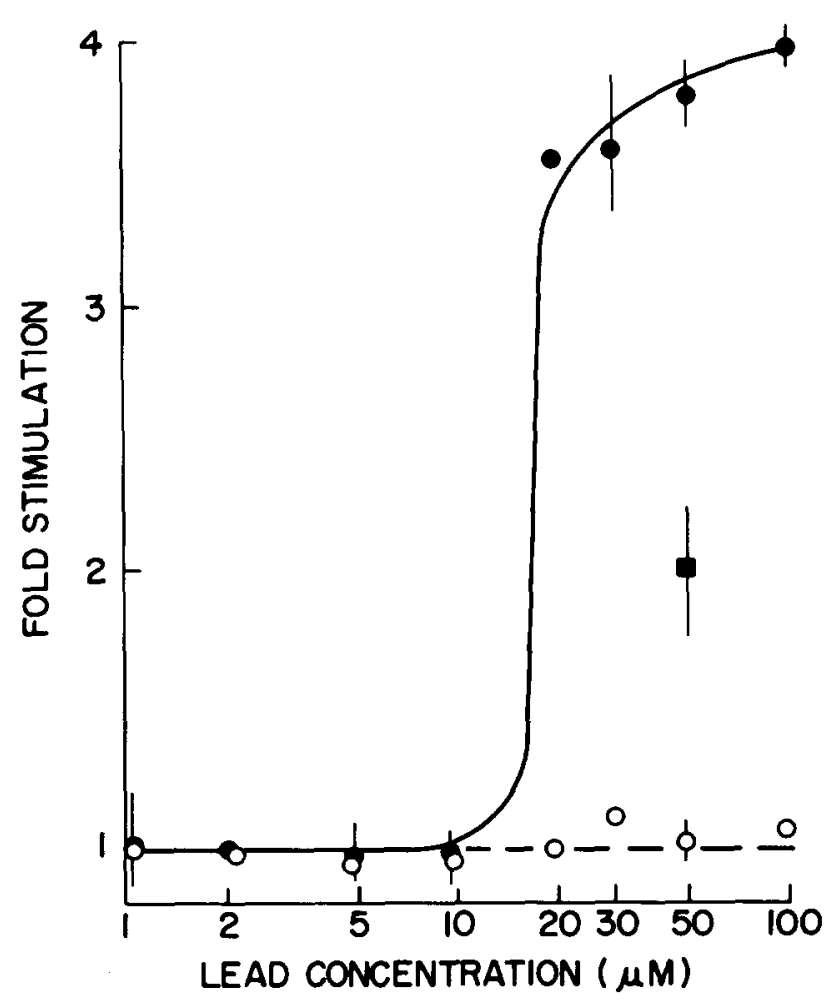

FIG. 1

Effect of increasing lead concentration upon PDE. Enzyme activity was measured in the presence (O) or absence (O) of added calmodulin. To inhibit calmodulin binding, $20 \mu \mathrm{M}$ TFP was added ( when the lead concentration was $50 \mu \mathrm{M}$. Incubations were performed in triplicate and results are expressed as the fold-stimulation of PDE + S.D. The basal activity of PDE was 180 pmol adenosine formed per $\overline{1} 0 \mathrm{~min}$. Where not shown, the deviations were less than $5 \%$ of the mean. Stimulation of PDE by lead required the presence of calmodulin and was inhibited by TFP.

If lead functions as a calcium agonist in the activation of calmodulin, it should alter calmodulin dependent cell functions that normally respond to changes in the cytosol concentration of ionized calcium. By either energy depleting erythrocytes or treating them with a calcium specific ionophore, A23187, it is possible to raise their cytosolic concentration of calcium (14). One response to such an elevation is a marked increase in the permeability of the cell membrane to potassium (15). The effect is selective and not associated with loss of intracellular sodium. We found that potassium loss produced in this fashion was largely prevented by preincubating the red blood cells for 5 minutes with $20 \mu \mathrm{M}$ TFP (Fig. 2). This is the same concentration of TFP that inhibits calmodulin activation of calcium regulated enzymes (7). 


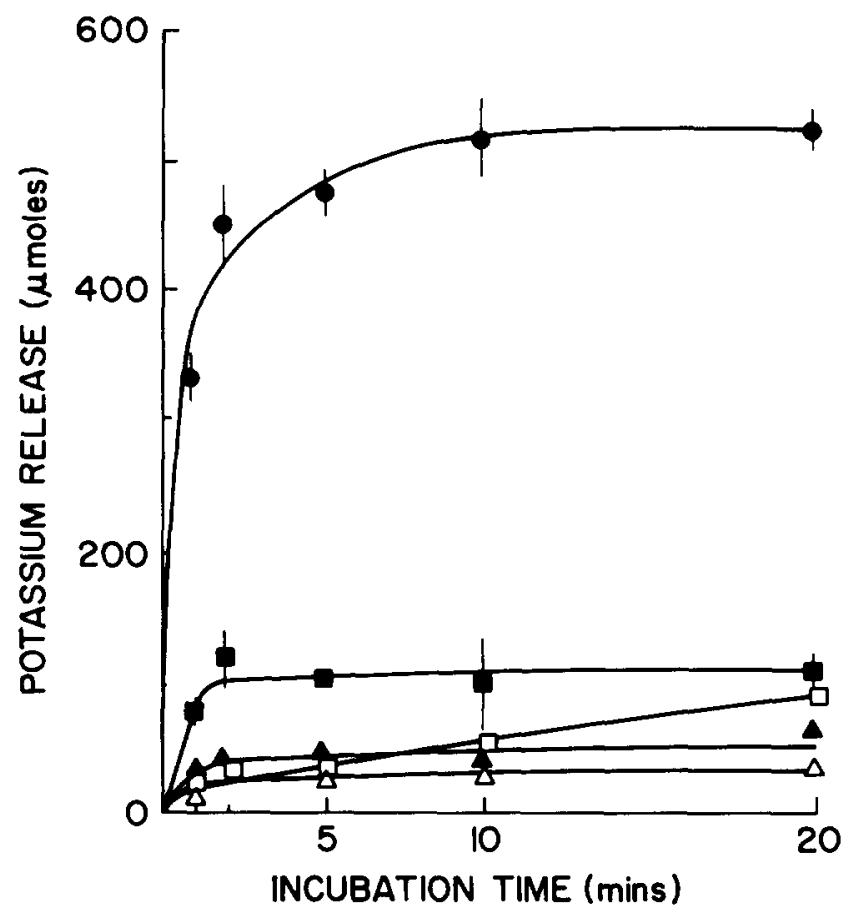

FIG, 2

Effect of TFP on the release of potassium from human red blood cells treated with calcium ionophore, A23187. Incubations were performed in the presence of $0.2 \mathrm{\mu g} / \mathrm{ml}$ ionophore alone (C), ionophore with $10 \mu \mathrm{M}$ EGTA $(\boldsymbol{\Delta})$, ionophore with $20 \mu \mathrm{M} \operatorname{TFP}(\boldsymbol{D})$, EGTA alone $(\boldsymbol{\Delta})$, or TFP alone ( $\square$ ). The results are averages of three determinations + S.D. Where not shown, the deviations were less than $5 \%$ of the mean. The release of $\mathrm{K}^{+}$promoted by the calcium ionophore, A23187, was inhibited by TFP. In addition, it was largely prevented by chelation of calcium with EGTA prior to addition of the ionophore.

Although TFP has effects in addition to calmodulin blockade, other biologic events which are inhibited by micromolar concentrations of TFP have been assumed to be mediated by calmodulin $(5,16)$. Thus, this observation implicates calmodulin in, the regulation of potassium permeability by the cytosolic concentration of calcium in red blood cells. Exposing red blood cells to lead also rapidly leads to selective potassium loss (17). Unlike the calcium effect, there is no need to energy deplete the cells or add an ionophore since lead readily enters red blood cells. We found that the same $20 \mu \mathrm{M}$ concentration of TFP that inhibited the loss of potassium from red blood cells with a raised calcium concentration (Fig. 2) also prevented the 10 ss of potassium from red blood cells exposed to lead (Fig. 3). These findings suggest that both calcium and lead produce potassium loss from erythrocytes by activating calmodulin. The possible significance of this observation to lead poisoning is supported by the similarity between the threshhold for the leadinduced permeability change in erythrocytes $(5-10 \mu \mathrm{M})$ and the concentration of lead in the blood of children with symptoms of lead poisoning (18). 


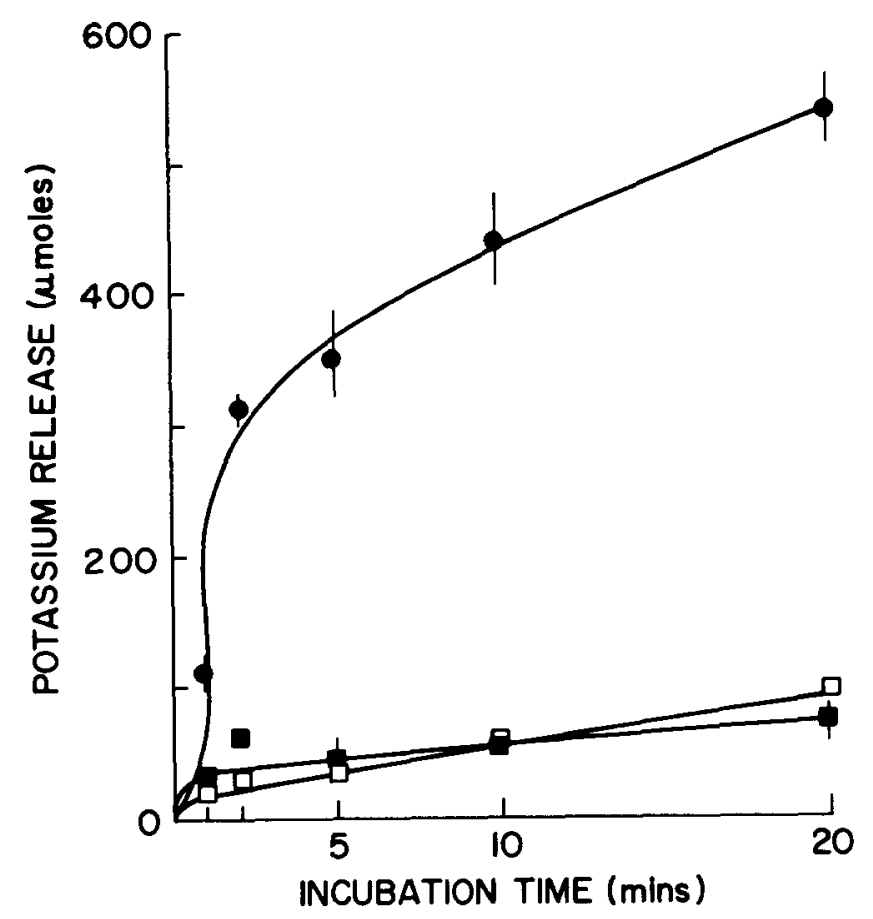

FIG, 3

Effect of TFP on the release of potassium from human red blood cel1s treated with lead. Incubations were performed in the presence of

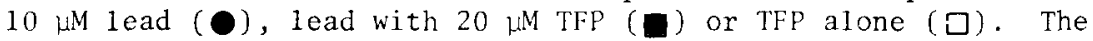
results are averages of three determinations \pm S.D. Where not shown, the deviations were less than $5 \%$ of the mean. The release of $\mathrm{K}^{+}$ promoted by lead was blocked by TFP.

In a study of heavy metal interaction with.cyclic nucleotide metabolism, Nathanson and Bloom described a marked inhibition of adenyl cyclase by lead and other heavy metals (19). Competition at the calmodulin binding site seems unlikely for this effect since high concentrations of calcium did not reverse the inhibition. In addition, they observed a $22^{\circ}$ stimulation of PDE by lead while other heavy metals were without effect. The relation of calcium and calmodulin to the stimulation of PDE by lead was not investigated.

We found that lead can replace calcium in the activation of calmodulinsensitive PDE and in the promotion of potassium loss from red blood cells. Both processes were inhibited by low concentrations of TFP. Taken together, these observations support a molecular model for lead toxicity in which lead alters the function of a tissue by entering the cell and occupying calcium binding sites on calmodulin. Since calmodulin regulates multiple cell activities and is present in virtually all tissues, this mechanism may 
underlie some of the diverse effects of lead poisoning. Tissue differences in lead permeability, calmodulin concentration, calmodulin-sensitive functions, and internal calcium concentration might explain in part the different thresholds and responses of various organs to the toxic effects of lead.

\section{Acknowledgements}

This research was supported by grants from the National Institutes of Health (\#ESO2380) and the March of Dimes Birth Defects Foundation (\#1-706).

\section{References}

1. R. A. GOYER, and B. C. RHYNE in Internationa1 Review of Experimental Pathology, Volume 12, edited by G. W. Richter and M. A. Epstein. Academic Press, New York (1973).

2. J. C. BARTON, M. E. CONRAD, L. HARRISON and S. NUBY, J. Lab. \& Clin. Med. 91, 366-376 (1978).

3. J. R. DEDMAN, J. S. TASH and A. R. MEANS in Laboratory Methods Manual for Hormone Action and Molecular Endocrinology, Fourth Edition, edited by W. T. Schrader and B. W. O'Malley. Houston Biological Assoc., Inc., Chapter 10 (1980).

4. J. STOCLET, Biochem. Pharmacol. 30, 1723-1729 (1981).

5. W. Y. CHEUNG, Federation Proceedings 4l, 2253-2257 (1982).

6. C. O. BROSTROM and D. J. WOLFF, Biochem. Pharmaco1. 30, 1395-1405 (1981).

7. R. M. LEVIN and B. WEISS, Mol. Pharmacol. $12,581-589$ (1976).

8. J. G. POUNDS, R. WRIGHT and R. L. KODELL, Toxicology \& Applied Pharm. 66, 88-101 (1982).

9. P. A. MEREDITH, M. R. MOORE and A. GOLDBERG, Biochem. J. 166, 531-537 (1977) .

10. F. S. HSU, L. KROOK, J. N. SHIVELY, J. R. DUNCAN and W. G. POND, Science $181,447-448$ (1973).

11. G. W. GOLDSTEIN, Brain Res. 136, 185-188 (1977).

12. K. M. SCOTT, K. M. HWANG, M. JURKOWITZ and G. P. BRIERLEY, Arch. Biochem. Biophys. 147, 557-567 (1971).

13. R. M. LEVIN and B. WEISS, Mol. Pharmacol. 13, 690-697 (1977) .

14. D. R. PFEIFFER, R. W. TAYLOR and H. A. LARDY, Ann. New York Acad. Sci. $307,402-421$ (1978).

15. V. L. LEW and H. G. FERREIRA, Current Topics in Membranes and Transport $10,217-277(1978)$.

16. N. E. OWEN and M. L. VILlereAl, Proc. Nat1. Acad. Sci. USA 79, 3537-3541 (1982).

17. J. R. RIORDAN and H. PASSOW, Biochim. Biophys. Acta 249, 601-605 (1971).

18. J. S. LIN-FU, NEJM 289, 1229-1233 (1973) .

19. J. A. NATHANSON and F. E. BLOOM, Mol. Pharmacol. 12, 390-398 (1976). 